\title{
Salient Features of Chinese Historical Thinking
}

\author{
Chun-chieh Huang \\ Professor of History \\ National Taiwan University \\ Research Fellow, Academia Sinica
}

\begin{abstract}
Imbued with profound historical consciousness, the Chinese people are Homo Historiens in every sense of the term. To be human in China, to a very large extent, is to be historical which means to live up to the paradigmatic past today. Therefore, historical thinking in traditional China is moral thinking. The Chinese historico-moral thinking centers around the notion of dao that is Heavenly principle and simultaneously human norm.

In view of its practical operation, the Chinese historical thinking is, on the one hand, concrete thinking and, on the other, analogical thinking. Thinking concretely and analogically, the Chinese people become able to communicate with the past and extrapolate meanings from history. In this way, historical experience in China becomes a library in which the contemporary readers may engage creative dialogues with the past.
\end{abstract}

\section{Introduction}

Since time immemorial, China has been noted for her historical-mindedness. The Chinese people and their society have been living under the tutelage of history. The Chinese mind has been deeply dipped in the spirit of history, as the founding emperors in imperial China always sought to legitimize their dynasties in history. In the same vein, the Chinese people always turned to history to justify a revolution of its politics and culture.

This article explores the peculiarities of the Chinese historical thinking. In Section two, we consider the significance of history in China, and in the third section we delve into the significance of the historical thinking that Chinese people live, followed by concluding observations in the final section.

\section{The Significance of History in China}

2:1 China has been imbued with the writing of history since as early as at least 841 B.C. During all these years, the Chinese people have been able to "look at the past from the present" and judge and shape the present in the light of the ideal past, and to judge the past in the light of the present ideals thus shaped. Such factual judgment and judgmental description were taken with absolute seriousness. To get at the real facts has been an all-consuming passion of Chinese historians, so much so that some of 
them sacrificed their lives in opposition to their rulers' pressures on them to write otherwise than what they believed to be true in fact. For instance, in 548 B.C. (the year twenty-fifth of the reign of Duke Xiang 襄公 of the State Lu 魯, a "grand historian" who was an official of historiography, recorded, “Cui Shu 崔抒 assassinated his ruler." Cui Shu angrily had that grand historian executed. Then, his younger brother took over the office of grand historian, and recorded the identical statement, and was likewise executed. Next came the second younger brother, who recorded again the identical statement, and so on, up till the fourth brother! At this point, Cui Shu had to give up the idea of rewriting or "erasing" history. ${ }^{1}$ Historians in China are indeed the incarnation of conscience who devote their lives to recording and preserving the facts.

This is the reason why the historians' words were taken quite seriously in traditional China. "To receive [the historian's] single word of praise is to be glorified beyond high emolument; to be accused by his slightest word of blame is to be punished beyond [hacking of] axes.” asserted the literary critic Liu Xie (劉妿思, 456?-520?) in his The Literary Mind and the Carving of Dragon (Wenxin Diaolong , 文心雕龍). ${ }^{2}$

2:2 In traditional China, history is as much shaped by human pathos in reflective and often tragic living as the Chinese people are integrated meaningfully or disintegrated pathetically with the vicissitudes of Chinese history. This is because, as the great historian in the twentieth-century China, Qian Mu (錢穆, 1895-1990), said in his The Spirit of Chinese History (Chungguo Lishi Jingshen, 中國歷史精神), "National history awakens the soul of a nation," for "history is the whole experiences of our life, the whole life past. We can understand our life by referring ourselves to history. History can thus allow us to appropriately project our life into the future."3

In other words, history in China is taken as the crystallization of past personal life experiences. By the personal is meant that the meaning of personal life is discovered, interpreted and shaped by the history in which one is situated. In Chinese context, to live humanly is to be historically oriented.

All Chinese historians believe that history lets us understand ourselves and plan

\footnotetext{
${ }^{1}$ Yang Bojün, Chunchiu Zozhuan Zhu 春秋左傳注 (Taipei: Yüanliu publishing Co, 1982), vol.2, p.1099. For English translation, see The Tso Chuan, tr., Burton Watson (NY: Columbia University Press, 1989), p.147.

2 Pu Qilong, Wenxin Diaolong zhu (Taipei: Kaiming Bookstore, 1968), vol.4, p.1.

3 Qian Mu, Chungguo Lishi Jingshen 中國歷史精神 (The Spirit of Chinese History), in Editorial Committee of Mr. Qiam Binsi’s Complete Works ed., Qian Binsi Qüanji 錢賓四全集 (Taipei: Lianjing Publishing Co., 1998), Vol.29, p.6. The nationalistic sentiment in Qian Mu's historiography reminds us Jules Michelet (1798-1874) when he said in his introduction to his The people (1864)(translated by P. McKay. Urbana: The University of Illinois Press, 1973), "This book is more than a book; - it is myself. That is the reason it belongs to you. Yes, it is myself; and, I may venture to affirm, it is you also. All our various works have sprung from the same living root. - The sentiment of France, and the idea of our country." See Fritz Stern ed., The Varieties of History: From Voltaire to the Present (New York: Meridian Books, 1956), p.109. For a discussion of history as "national epic" in twentieth-century China, cf. Ying-shih Yü, "Changing Conceptions of National History in Twentieth-Century China," in Erik Lönnroch, Karl Molin and Ragnar Björk eds., Conceptions of National History: Proceedings of Nobel Symposium 78 (Berlin and New York: Walter de Gruyter, 1994), pp.155-174.
} 
our future because history, as seemingly neutral, is the description of what happened, and precisely because of that, it provokes us to formulate some universal principles of life. Ironically, this becomes most apparent when historical facts challenge our initial facile convictions. The Grand Historian Sima Qian (司馬遷, 145?-87? B.C.) was deeply troubled as he confessed in his classic, Historians Records (Shiji, 史記), ${ }^{4}$

Some say, 'Heaven's way favors none, but always sides with good men. Can men such as Bo Yi and Shu Qi be called good then, or bad? They accumulated such virtue, kept their actions this pure, and died of starvation.

Of his seventy disciples, Confucius recommended only Yen Yüan 顏淵 as 'fond of learning.' But Hui 回(Yen Yüan)was often poor,' and did not get his fill of even rice dregs and husks, finally dying young. How then does Heaven repay good men?

The Bandit Zhi 盗跖 killed innocent men daily, made delicacies from men's flesh, was cruel and ruthless, willful and arrogant, gathered a band of thousands of men and wreaked havoc across the world, yet finally died of old age. From what virtue did this follow?

These are just the most notorious and best known examples. As for more recent times, men who do not follow what is proper in their actions, and do nothing but violate taboos are still carefree and happy for all their lives and wealthy for generations without end; men who choose carefully how they tread, wait for the right time to offer their words, in walking do not take shortcuts, and except for what is right and fair do not vent pent-up emotions, still encounter disaster and catastrophe in numbers beyond counting. I am deeply perplexed by all this. Perhaps this is what is meant by 'the Way of Heaven.' Is it? Or isn't it?

或曰: 「天道無親, 常與善人。」若伯夷、叔齊, 可謂善人者非邪? 積仁絜行 如此而餓死, 且七十子之徒, 仲尼獨薦顔淵為好學。然回也屡空, 糟穅不厭, 而卒虫天。天之報施善人, 其何如哉? 盗蹠日殺不幸, 肝人之肉, 暴戻恣睢, 聚黨數千人横行天下, 竟以壽終。是遵何德哉? 此其尤大彰明較著者也。若至 近也, 操行不軌, 專犯忌諱, 而終身逸樂, 富厚累世不絕。或擇地而蹈之, 時 然後出言, 行不由徑, 非公正不發憤, 而遇禍災者, 不可勝數也。余甚惑焉, 儻所謂天道, 是邪非邪?

As Sima Qian lamented, we also are deeply troubled by the unfolding of "the Way of Heaven" in history. History's display of such affronts to our sense of justice provokes in us our profound value judgment. Reading the historical account of how good people fared and how evil ones did, we hate the evil fellows with hatred and cherish the sagely good with yearning - no matter how they fared, and in fact precisely

${ }^{4}$ William H. Nienhauser, Jr., ed., The Grand Scribe's Records (Bloomington: Indiana University Press, 1994), vol.VII, The Memoires of Pre-Han China, p.4. 
because they fared against our conscientious expectations! This is not to prove any law of retribution in life, but to confirm in a heartfelt manner our deep moral conviction.

Specifically, the Chinese historians believe that historical provocation of intense indignation at how evil ones prospered leads us to realize the intrinsic value of the sagely and the intrinsic disvalue of the evil ones, independent of how they fared. Importantly, it is through "how they fared" that we are provoked to righteous indignation at the unfairness and the injustice, of evil ones prospering and good ones dying young in starvation or in misfortune.

In other words, it is by thus negating the negative that the positive is manifested, which is the Dao (way, 道)and or the $L i$ (principle, 理) that is both the law of the universe and the norm of humanity, for we would now instinctively scorn people who would plan their lives just in order to prosper as Bandit Zhi (盗跖) did, and we loathe enemy informants although we may grudgingly pay them for the convenience they give us. This is how Chinese people come to "praise the good and blame the evil," formulate the heartfelt values, intrinsically and universally valuable, independent of what would actually happen.

2:3 This heartfelt feeling came, first, to be formulated in explicit formulae, and then applied to judge actualities both of the former times and the present situation. In this way, the so-called "hermeneutic circle" is actualized in the traditional Chinese historical thinking. First, we get the sense of universal principle Dao of justice from history, then to apply it to history in which the present is situated, and finally, it is thus that the circle of history of understanding is accomplished. Let us see how the procedure goes.

First, the intense sense of meaning of history can be extrapolated and appropriated from the historical facts. As Mencius (371?-289? B.C.) said, ${ }^{6}$

After the influence of the true King came to an end, songs were no longer collected. When songs were no longer collected, the Spring and Autumn Annals were written. The Sheng of Jin, the Dao Wu of Zhu and the Spring and Autumn Annals of Lu are the same kind of work. The events recorded concern Duke Huan of Qi and Duke Wen of Jin, and the style is that of the official historian. Confucius said, "I have appropriated the didactic principles therein."

\footnotetext{
${ }^{5}$ This is as Sima Qian quoted Dong Zhongshu's (c179-104 B.C.) words in Sima's celebrated Preface to Historian's Records (Shiji). See Sima Qian, Shiji (Taipei: Taishun Bookstore Photo-reproduction of new punctuated edition, 1971), vol.130, "The Grand Scribe's Preface," p.3297. The very process of quotation here is history. And Sima personally experienced this sentiment when he received a tragic punishment (castration) for his honestly assuring the emperor his devoted friend's loyalty to the state who yet ended up capitulating to the enemy. His punishment occasioned the writing of the Shiji, which is the Chinese version of Historia Calamitatum, to vindicate his sense of "historical justice."

${ }^{6}$ D.C.Lau tr., Mencius (Hong Kong: The Chinese University Press, 1979, 1984), vol II, BK IVB, p.165.
} 
王者之跡熄而詩亡, 詩亡然後春秋作。晉之乘, 楚之檮机, 鲁之春秋, 一也： 其事則齊桓、晉文，其文則史。孔子曰：「其義則丘船取之矣。」

Ever since the time of Confucius (551-479B.C.), Chinese historians have made efforts to appropriate didactic principles from history. This became especially true since the tenth century. For example, Sima Guang (司馬光, 1019-1086) in his Records of the Ancient History (Chigulu , 稽古錄), ${ }^{7}$ said, “The ruler's Dao is one, his virtues are three, his talents are five. . . Since the beginning of peoples and throughout the ultimate recess of Heaven and earth, there are nothing other than these to ones who possess the state through its ups and downs." The Neo-Confucian philosopher Zhu Xi (朱喜, 1130-1200) systematized the above informal expression in a more perceptive manner, by proposing $L i$ (principle) that describes the Way things operate and prescribes the Norm humanity should live by. More often than not, the philosophical argumentation in China was made possible by historical narration. ${ }^{8}$

Secondly, this $L i$ or Dao obtained by observing history became the concrete general norm and lever whereby the historians judged, admonished, and even remonstrated with the rulers, both in the past and at present. Zhu Xi boldly declared,

Fifteen hundred years are all like this, going through days merely patching and fixing the status quo. During this period [days of] 'small peace' were not lacking, but not a day passed without the Way transmitted by Yao, Shun, Three Kings, Duke Zhou, and Confucius being neglected in practice in the world. Yet, nobody has anticipated the permanent presence of the Way. This is the only thing that has been everlasting, in ancient days and today, always present, never perishing, indestructible despite fifteen hundred years of deeds of destruction by humans. ${ }^{9}$

千百五年之間, 正坐如此, 所以只是架漏毫補過了時日。其間雖或不無小康, 而堯舜三王周公孔子所傳之道未嘗一日得行於天地之間也。若論道之常存, 卻 又初非人所能預。只是此䇢, 自是互古互今, 常在不滅之物。雖千五百年被人 作壞, 終覀滅他不得耳。

Although worldly affairs are in the thousands and hundreds of thousands, really there is but one single Way, Principle. This is what is called 'Principle One, manifestations many.' 10

世間雖千頭萬緒, 其實只一箇道理, 「理一分疏」之謂也。

According to $\mathrm{Zhu} \mathrm{Xi}$, the $\mathrm{Li}$ derived from history became the standard for the critique of

7 Sima Guang, Jigulu (Xüejin taoyüan edition 學津討源本), juan 16, p.75-78.

8 See my "The Philosophical Argumentation by Historical by Historical Narration in Sung China: The Case of Chu Hsi," in Thomas H. C. Lee ed., The New and the Multiple: Sung Senses of the Past (Hong Kong: The Chinese University of Hong Kong, 2004), pp.61-106.

9 Zhu Xi, Hui'an xiansheng Zhu Wengong wenji 晦庵先生朱文公文集 (Taipei: Zhongwen Chubanshe photo-reproduction of the kinsi kanseki sokan 近世漢籍叢刊 edition, 1972), hereafter as Wenji, juan 36, “Da Chen Dongfu 答陳同甫,” p.2306.

${ }^{10}$ Li Jingde 黎靖德 ed., Zhuzi Yülei 朱子語類 (Beijing: Zhonghua shujü,1981), juan 136, p.3243. 
history, past and contemporary. The standard embodies historical flesh and blood, filled with tears of suffering people, labors of workers in the searing sun, lived devotion of loyal subjects and filial sons, brutalities of insensitive officials, virtuous lady's courageous chastity, and so on. The law and principle are both solidly based on the facts of history and universally applicable as norms of humanity and dynasties. In China, politics as an academic subject is basically history; as strategic deliberation it is based on history. Legal decisions in the court must consult records of precedents in history.

Finally, we see that it was thus that the "circle" of understanding and interpretation came about. Historians in China observed intently the historical processes to obtain from them some universal principles - both descriptive and prescriptive - so as to apply them as prescriptions and judgments to history itself, both in the past and at present. This circle is called "hermeneutic circle" that solidifies our concrete universal "historical thinking," which guides daily comportment of each individual on the one hand, and the vast cosmic ongoing of the entire world on the other. This expresses the ultimate essential importance of history in China.

\section{The Sense of Time in Chinese Historical Thinking}

The above discussion of the significance of history in China has much to do with the sense of time in Chinese historical thinking. The Chinese mind centers on and revolves around history. In China, to be human is to be historical. The Chinese people believe that we are human because we think and behave historically. Thus, to understand Chinese culture, and how peculiar it is, it becomes important to understand what history is, and how historical thinking works.

3:1 In the Chinese mind, history describes how aware we are of being in time that flows as we engage in various activities in the world. Since the "flow" includes its direction, to be aware of being in time means to have a sense of direction. This direction of time flows from what has passed through what is now to what is coming; our activities clearly go from the past through the present to the future in its unmistakable direction.

Such going in a definite direction gives us the prospect and purpose of living. Chinese people are particularly sensitive to this sense of time. To have this sense of time is to have purpose in life. Confucius (551-479 B.C.) stood at the bank of the "river of time," and sighed, "Oh, how it flows day and night, without ceasing!"11 In contrast, to lose this sense of time-direction is to be exiled out of living itself, to feel "out of place," unspeakably lost and lonesome in the world. Chen Zi'ang (陳子昂, 662-702) of T'ang Dynasty (618-907) sighed long, saying, "Beholding no ancients,/ Beholding no one's coming,/ Vainly thinking how vast the skies and broad the earth,/ Being alone, I

${ }^{11}$ Confucius, tr. by D. C. Lau, The Analects (Hong Kong: The Chinese University Press, 1992),BK IX, Chap.17, p.81. 
lament, shed tears."

In Chinese tradition then, the sense of history is the warp and woof of life, and the important indicator of how the society should be managed, how politics should be conducted for social stability and prosperity. Concretely, every time a dynasty replaced another, often at a considerable cost of bloodshed, a question about the legitimacy of the new regime was earnestly raised in terms of history. "Why did the Qin Dynasty (221-206 B.C.) lose the world, why did the Han Dynasty get it?" was hotly debated at the dawn of Han Dynasty (B.C. 206-220 A.D.). ${ }^{12}$ At the same time, based on this legitimacy with the concrete causes of Qin losing the "Mandate of Heaven" and Han obtaining it, people in and out of the royal palace eagerly discussed concrete measures of how best and most appropriately the new regime should govern and manage the world.

3:2 In all these debates and deliberations, history served as an important weathervane and concrete guide. History justified the legitimacy of Han to overthrow Qin, ${ }^{13}$ and history provided guidance to the current Han administration to back up its legitimacy by "good governance", and to keep a watchful eye over the ruler to stick to their vows and declarations to enforce good governance. Since the Tang Dynasty, such historic responsibilities of watching and warning over the throne fell on the writing brushes of the office of the Historiographers who compiled the Emperor's Qijü zhu (diaries of activity and repose, 起居註). The historiographers kept such a daily journal of Comments in strict confidentiality and with meticulous conscience. They never wavered in their duty, sternly kept the Comments out of the Emperor's eye, and literally devoted their lives to fulfilling the duty. Such has been the Chinese utter devotion to history.

In short, we are warranted in saying that in China, the society, the people, the culture, the politics, all are history. To contact the Chinese and their culture is to contact their history. Their history constitutes their flavor, their atmosphere, in fact, the very existence of China. Chinese history is the very flesh and blood of China. The people, politics and culture in China is its history. China is the place where we see most clearly that the human being is homo historiens through and through.

\section{Two Outstanding Aspects of Chinese Historical Thinking}

Now, we are in a better position to appreciate the defining characteristics of Chinese historical consciousness. In traditional Chinese historical thinking, history is formed as the people think analogically and concretely about the events of life. We

12 Sima Qian, "Biographies of Li Sheng and Lu Jia," in Shiji (Taipei: Taishun Bookstore Photo-reproduction of new punctuated edition), p.2699.

13 See my "The Ch'in Unification (221 B.C.) in Chinese Historiography," in Q. Edward Wang and Georg G. Iggers eds., Turning Points in Historiography: A Cross-cultural Perspective (Rochester: University of Rochester Press, 2002), pp. 31-44. 
proceed to explicate these two salient aspects of Chinese historical thinking.

4:1 In the first place, the Chinese believe that history is formed in and by our analogical thinking. Analogy is not an abstract logic that cuts us off from concrete details. It is neither wild imagination that is baseless and haphazard, nor sporadic reports of isolated events without rhyme or reason. Analogy is instead concrete, systematic, open-ended, and so comprehensive. Analogy has two features: it is metaphorical and it takes a part for the whole (pars pro toto).

First, analogical thinking is "metaphorical." Liu Xiang (劉向, 77-6 B.C.) of the Han Dynasty in his Shuo Yüan (說苑) quoted the famous logician Hui Shi (惠施, 380-305 B.C.), saying, "Pi 辟 is to analogize the unknown by the known,"14 as the "Appended Remarks" of the Book of Changes ( Yijing, 易經) says, “taking what are close by our bodies, taking things from afar" (近取諸身，遠取諸物) $)^{15}$ to know and judge things far and unknown.

The Chinese people keep to the representative historical cases in drawing generalizations. The factual case is the "knot" of the "cord" of actuality. This contrast shows in different usage of "exemplum," that is, a short story as metaphor. Whenever the Chinese thinkers want to "argue" some universal principles or draw some moral codes, they always return to concret historical examples or experience. Mencius (371-289? B.C.) is a good representative thinker in this context. In "articulating" his moral philosophy, Mencius cited many historical examples of famous people such as Shun (舜), Fu Yüe (傅說), Jiao Ge (膠鬲), Guan Zhong (管仲), Sun Shu'ao (孫叔敖) and Boli Xi (百里罙). Then he said that Heaven exhausts one's frame in starvation, hardship and frustration before placing on one a great burden and thereby provoking innovation. ${ }^{16}$ Exemplum in the West is an illustration, dispensable, decorative, of an abstract thesis, "conditioning" that stands by itself; Pavlov's Dog is just its decoration, its illustration. In contrast, Chinese notions collapse when abstracted from the exempla they point to. Zhuangzi's (399?-295?B.C.) “double walk (liang xing, 兩行)" is senseless without that monkey story, to the effect that, since the "morning, three [nots], evening, four" bananas that that Monkey Keeper proposed was booed by monkeys, the Keeper switched to "morning, four, evening, three," to win their approval, thereby did the "double walking" of fulfilling both desires, his and the monkeys'. ${ }^{17}$ This concrete story is indispensable notable (that is, "notion") that actually "knot" the "cord" of actuality as no abstract concept can.

Metaphor in China is thus an essential part of its thinking; metaphor in the West is a dispensable decoration. We may describe different uses of metaphor in two cultures with a rather dated metaphor. The West inserts metaphor as a feather onto a hat, while

14 Liu Xiang, Shuoyüan 說苑 (Sibu congkan soben edition), juan 11, p.51.

15 Gao Heng, Zhouyi Dazhuan jinzhu 周易大傳今注 (Jinan: Jilu shushe, 1979), juan 5, pp. 558-559.

16 D.C. Lau tr., Mencius, BK 4:B (B refers to the later part of the book), pp.261-263.

17 Burton Watson tr., The Complete Works of Chuang Tzu (New York and London: Columbia University Press, 1968), Chap.2, “Discussion on Making All Things Equal,” pp.36-49, esp. pp.40-41. 
China fits metaphor as a feather onto an arrow. A Chinese arrow of idea cannot fly straight to its targeted intention without its feather, metaphor, which is just a feather on a Western hat of idea to call our attention, having little to do with the function of a hat itself.

Secondly, such analogical thinking often takes "a part for the whole (pars pro toto)," for example, taking "bread" as "food" in general, taking "flag" as "the entire nation." By the same token, historians often pick one event, one view, ancient or modern, in whose terms and in whose perspective to describe the entire situation. They use one point of view to confirm or even protest the entire situation of the past. The last extreme case is Sima Qian who in his Historian's Records protested as unfair the facts of righteous Bo Yi (伯夷) and Shu Qi (叔齊) having had to starve to death in his perspective that "Heaven is always on the side of good people."

Again, the West often takes argumentation as "war," as "winning" or "losing" an argument. Such an attitude disregards argument as midwifery dialogue ${ }^{18}$ or exhortation and persuasion with metaphors, as often happens in China.

In general, we inevitably think from one perspective, picking one perspective to comprehend all-the whole situation-and so our comprehension is inevitably restricted to one aspect of the situation highlighted by that perspective (argument as war) and turns blind to other aspects (argument as midwifery, as persuasion).

4:2 In the second place, another feature of analogical thinking in Chinese historical thinking is coherence. To think is to think coherently, of course, and our history forms as we think coherently. We re-walk, re-enact, and re-describe the days gone by and form our story of life and our history.

"History" means some truthful, straight, and objective description. Even "feigned" history has its root in "the soil of experience." All this sounds like straight from the confessions of a conscientious journalist. In fact, today's journalist is exactly like the official historiographer in traditional China who was a solitary brilliant star in the brutal glorious or gloomy past of bygone dynasties. Both the journalists now and the "historians" then have their historical conscience. They determined to report what actually happened to readers - contemporaries or posterity - to let them form their own opinions and apply the lessons they draw to their own times and circumstances.

So far, we have seen how historians in China look at the past in terms of our present, namely, by way of metaphorical analogical thinking, and thinking by operating on a part to coherently cover the whole.

\section{Conclusions}

In this paper, I argue that history occupies the pivotal position in the make-up of

18 Cf. George Lakoff and Mark Johnson, Metaphors We Live By (Chicago: University of Chicago Press, 1980), pp. 3-13. 
the world view and philosophy of life in the Chinese tradition. The Chinese people are Homo Historiens through and through. The Chinese people have a profound sense of time in their historical consciousness. Facts, events and personages are considered and evaluated against the context of the "flow" of time. At the very core of Chinese historical thinking, lies the notion of $d a o$ or $l i$ with which the Chinese historians pass value or moral judgments upon historical actuality. In this sense and to that extent, the Chinese historical thinking is a kind of moral thinking. However, ethics in Chinese historical thinking is grounded in metaphysics, which is centered upon the notion of dao or $\mathrm{Li}$ that comprise both principle and norm. This twofold-ness of metaphysics in Chinese historical thinking is, on the one hand, a very powerful lever by which historians can judge any historical figures, but it is, on the other hand, a double-edged sword that cut short historians' explanatory power in accounting for the evils in history.

Moreover, the Chinese historical thinking is something like a shuttling movement between the past and the present for mutual enrichment. The past experience is not dead and wrapped like the mummies in Museums, but alive and interactive like the library in which the present-day readers may enter to engage in creative dialogues with the historical figures. All these "conversations" were made possible by the analogical as well as the concrete thinking which constitute the two outstanding constituents of the Chinese historical thinking. 